\title{
Konsumsi Mamalia, Burung, dan Reptil Liar Pada Masyarakat Sulawesi Utara dan Aspek Konservasinya
}

\author{
Saroyo ${ }^{1)}$ \\ 1) Jurusan Biologi Fakultas MIPA Universitas Sam Ratulangi Manado \\ "E-mail korespondensi : yoyoksumarto@lycos.com
}

Diterima 26 Juli 2011, diterima untuk dipublikasikan 1 Agustus 2011

\begin{abstract}
Abstrak
Survei ini dilaksanakan untuk menginventarisasi jenis-jenis mamalia, burung, dan reptil liar yang dikonsumsi oleh masyarakat Sulawesi Utara dalam kaitannya dengan aspek konservasi dan pemanfaatannya. Metode yang digunakan dalam penelitian ini adalah survei dari tahun 2006 sampai 2010 berdasarkan jenis-jenis yang diperdagangkan di pasar-pasar tradisional, kasus perburuan satwa liar, dan jenis-jenis yang disediakan dalam menu masyarakat pada pesta-pesta adat. Dari survei diperoleh hasil terdapat 39 jenis mamalia, burung, dan reptil liar yang dikonsumsi oleh masyarakat Sulawesi Utara. Konsumsi satwa liar telah menjadi kebiasaan bagi bagi masyarakatnya dan merupakan faktor utama penyebab penurunan populasi satwa liar. Banyak jenis satwa yang dikonsumsi, beberapa termasuk dilindungi, masuk daftar terancam IUCN, dan masuk dalam appendix CITES. Oleh sebab itu pemanfaatan beberapa jenis satwa liar harus mengikuti peraturan perlindungan dan upaya penangkaran tikus ekor putih (Paruromys dominator), babi hutan (Sus celebensis), dan rusa (Cervus timorensis) sangat memungkinkan dan memiliki nilai ekonomi yang tinggi.

Kata kunci: burung, mamalia, reptil, Sulawesi Utara
\end{abstract}

\begin{abstract}
This survey was conducted to collect information about wild mammals, birds and reptiles consumed by North Sulawesi people regarding with its conservation aspect and utilization. The used method was survey from 2006 to 2010 based on the animal species sold in some traditional markets, hunting cases and serving food in traditional party menu in Bitung City, Tomohon City and North Minahasa District. The result showed that there were 39 consumed species of wild mammals, birds and reptiles. Consumption of wild animal by local people has become a tradition for the community and it mostly resulted in the decline of wild animal population. Some species are included in IUCN Redlist and CITES Appendices. Therefore, all protection laws should be followed in the utilization of those species. In addition, breeding programme of Sulawesi giant rat (Paruromys dominator), Sulawesi Wild Boar (Sus celebensis) and Timor Deer (Cervus timorensis), is very prospective as it has economically value.
\end{abstract}

Keywords: birds, mammals, reptiles, North Sulawesi

\section{PENDAHULUAN}

Indonesia merupakan negara megabiodiversitas tertinggi nomor dua di dunia. Hal ini berarti bahwa jumlah jenis makhluk hidup, termasuk flora, fauna, mikroba, dan jamur sangat tinggi. Beberapa faktor yang menyebabkan tingginya keanekaragaman hayati ini, antara lain, Indonesia merupakan negara yang luas, terdiri dari banyak pulau, terletak di zona tropis, mempunyai beragam ekosistem, dan merupakan pertemuan dua kawasan biogeografi 
utama, yaitu Asia dan Australia (Whitten et al. 1987).

Menurut perkiraan, hampir $10 \%$ dari hutan dunia dan hampir $40 \%$ dari hutan Asia terdapat di Indonesia. Dari semua jenis yang hidup di planet ini, Indonesia memiliki $12 \%$ mamalia, $16 \%$ burung, $10 \%$ reptilia, $7 \%$ amfibi, dan $25 \%$ jenis ikan (Kinnaird 1997).

Kawasan pertemuan antara dua biogeografi di Indonesia dikenal sebagai Kawasan Wallacea. Pada kawasan ini ditemukan flora dan fauna dari biogeografi Asia dan Australia sehingga keanekaragaman hayatinya sangat unik. Dari kawasan ini, Pulau Sulawesi memegang peranan penting dalam sejarah alam kawasan karena merupakan pulau terbesar di dalam Kawasan Wallacea. Sebagai pulau terbesar, Sulawesi dipandang dapat mewakili keanekaragaman hayati kawasan dan merupakan kawasan penting dalam berbagai penelitian biogeografi dan sejarah alam makhluk hidup (Saroyo dan Tallei 2010).

Ukuran pulau yang besar dan lamanya isolasi menyebabkan evolusi dari banyak jenis yang unik. Dari 127 jenis mamalia Sulawesi, 79 $(62 \%)$ di antaranya merupakan jenis endemik. Sulawesi merupakan salah satu dari Daerah Burung Endemik yang paling penting di Indonesia: dari 235 jenis burung darat, 84 jenis (36\%) di antaranya adalah endemik; dan dari 104 jenis reptilia, 29 (28\%) di antaranya adalah endemik Sulawesi (Sumarto 2010).

Walaupun demikian, kenyataan menunjukkan bahwa tingkat keterancaman keanekaragaman hayati di Sulawesi termasuk tinggi. Dua faktor penyebab utama adalah perusakan habitat dan perburuan untuk konsumsi. Faktor terakhir ini merupakan faktor yang bertanggung jawab terhadap merosotnya populasi satwa liar di Sulawesi Utara (BKSDA 2002 dan Lee et al. 2001).

Banyak jenis mamalia, burung, dan reptil liar telah menjadi menu umum maupun menu langka dalam berbagai pesta adat maupun makanan sehari-hari. Beberapa satwa merupakan jenis yang dilindungi dan jenis yang terancam menurut IUCN, dan masuk dalam daftar appendiks CITES, sehingga pemanfaatannya harus memperhatikan berbagai peraturan sehingga kelangsungan hidup di alam akan tetap terjamin.

\section{METODE}

1. Tempat dan Waktu Penelitian

Penelitian dilakukan di Sulawesi Utara yang meliputi Kota Bitung, Minahasa Utara, dan Kota Tomohon dari tahun 2006 sampai dengan 2010.

\section{Metode Penelitian}

Penelitian dilaksanakan dengan menggunakan metode survei. Dua informasi penting yang dikumpulkan selama survei meliputi jenis-jenis mamalia, burung, dan reptil liar yang biasa diburu, diperdagangkan di pasarpasar tradisional, dan jenis-jenis yang biasa disajikan pada pestapesta tradisional. Dua pasar tradisional yang disurvei setiap tahunnya adalah pasar Airmadidi dan pasar Tomohon. Semua jenis yang diperoleh selama survei diidentifikasi dan dirunut statusnya berdasarkan Lampiran 1 Daftar Appendiks CITES dan Daftar Merah IUCN. Identifikasi dilakukan dengan menggunakan beberapa buku Panduan Lapangan Burung-Burung di Kawasan Wallacea, Sulawesi, Maluku dan Nusa Tenggara (Coates dan Bishop 2000) dan Sulawesi Utara: Sebuah Panduan Sejarah Alam (Kinnaird 1997) 
HASIL DAN PEMBAHASAN

\section{Budaya Mengonsumsi Satwa Liar di Sulawesi Utara}

Menyediakan daging satwa liar dalam berbagai pesta adat oleh sebagian masyarakat Sulawesi Utara sudah menjadi budaya, bahkan beberapa komunitas mengharuskan tersedianya jenis satwa liar tertentu, misalnya daging penyu pada upacara pernikahan di sebagian masyarakat Pulau Lembeh. Untuk memenuhi kebutuhan akan daging satwa liar ini, sebelum pelaksanaan pesta adat masyarakat melakukan perburuan atau cukup membeli di pasar-pasar tradisional.

Di beberapa pasar tradisional, beberapa jenis satwa liar yang diperdagangkan untuk kepentingan konsumsi yang paling umum adalah kelelawar atau paniki (Pteropus ) dan tikus ekor putih (Paruromys dominator), sedangkan jenis-jenis lainnya seperti ular piton (Python reticulatus), babi hutan (Sus), dan penyu hijau (Chelonia mydas) hanya jika terdapat tangkapan. Jenis-jenis lainnya menjadi komoditas yang sangat langka, misalnya yaki pantat merah (Macaca nigra), yaki pantat hitam (Macaca nigrescens), kuskus (Ailurops ursinus), babirusa (Babyrousa babyrussa), anoa (Bubalus depressicornis) karena semakin sulitnya berburu satwasatwa tersebut. Sementara untuk jenis-jenis lainnya, biasanya dikonsumsi jika secara tidak sengaja mendapatkannya pada saat berburu satwa target lainnya, seperti yang secara tidak sengaja masuk perangkap, tertembak, atau terjala.

\section{Jenis-Jenis Mamalia, Burung, dan Reptil Liar yang Dikonsumsi dan Statusnya}

Beberapa jenis satwa liar
yang biasa dikonsumsi oleh
masyarakat Sulawesi Utara dan
statusnya disajikan pada Lampiran

1. Jenis-jenis ini didasarkan pada survei yang dilakukan di pasar-pasar tradisional, yaitu di Pasar Airmadidi dan Pasar Tomohon, serta praktek perburuan yang dilakukan masyarakat dan ketersediaan daging dalam pesta-pesta tradisional.

Khusus untuk burung, jenisjenis yang disajikan pada Lampiran 1 masih lebih sedikit dari yang biasa dikonsumsi karena masyarakat bisa mengonsumsi berbagai jenis yang tertangkap dalam perangkap atau tertembak dalam perburuan.

\section{Aspek Konservasi Satwa Liar yang Dikonsumsi}

Beberapa jenis satwa liar yang dikonsumsi merupakan satwa yang dilindungi oleh Pemerintah Indonesia, bahkan masuk dalam kategori terancam punah pada Red list IUCN (International Union for Conservation of Nature and Natural Resources), dan masuk daftar Appendix CITES (Convention on International Trade in Endangered Species of Wild Fauna and Flora). Beberapa jenis yang masuk dalam daftar satwa yang dilindungi berdasarkan Peraturan Pemerintah No. 7 Tahun 1999 tentang Pengawetan Jenis Tumbuhan dan Satwa, maka pemanfaatannya harus mengikuti berbagai aturan .

Menurut PP No. 7 Tahun 1999, pengawetan jenis bertujuan untuk menghindarkan jenis tumbuhan dan satwa dari bahaya kepunahan; menjaga kemurnian genetik dan keanekaragaman jenis tumbuhan dan satwa; dan memelihara keseimbangan dan kemantapan ekosistem yang ada agar dapat dimanfaatkan bagi kesejahteraan manusia secara berkelanjutan. Suatu jenis ditetapkan dalam golongan yang dilindungi apabila telah memenuhi kritena mempunyai populasi yang kecil; adanya penurunan yang tajam pada jumlah individu dialam; dan daerah 
penyebarannya yang terbatas (endemik).

\section{Dalam Peraturan Pemerintah}

No. 8 Tahun 1999 tentang Pemanfaatan Jenis Tumbuhan dan Satwa Liar dinyatakan bahwa hasil penangkaran satwa liar yang dilindungi dan dapat digunakan untuk keperluan perdagangan adalah satwa liar generasi kedua dan generasi berikutnya. Generasi kedua dan generasi berikutnya dari hasil penangkaran jenis satwa liar yang dilindungi, dinyatakan sebagai jenis satwa liar yang tidak dilindungi. Hasil penangkaran untuk persilangan hanya dapat dilakukan setelah generasi kedua bagi satwa liar yang dilindungi, dan setelah generasi pertama bagi satwa liar yang tidak dilindungi, serta setelah mengalami perbanyakan bagi tumbuhan yang dilindungi. Hasil persilangan satwa liar dilarang untuk dilepas ke alam.

Terkait dengan upaya penangkaran, satu jenis yang memiliki prospek untuk dikembangbiakkan adalah tikus ekor putih (Paruromys dominator). Walaupun sering kali jenis ini juga disebut tikus hutan, jenis ini sebenarnya tidak termasuk kelompok tikus karena tidak masuk ke dalam marga Rattus atau Mus. Bagi sebagian besar masyarakat Sulawesi Utara, jenis ini dikonsumsi dan telah menjadi menu istimewa dalam pesta-pesta adat.

Jenis lain yang potensial untuk dikembangbiakkan adalah babi hutan (Sus celebensis) dan rusa (Cervus timorensis). Hal ini didasarkan pada kerabat dekatnya yang sudah lama didomestikasi dan menjadi hewan peliharaan untuk kepentingan konsumsi sehingga kemungkinan besar upaya domestikasinya akan berhasil.

\section{KESIMPULAN}

Budaya mengonsumsi satwa liar di satu sisi dapat dipandang sebagai pemenuhan akan protein hewani, tetapi di sisi lain harus memperhatikan aspek pelestariannya terutama untuk jenisjenis yang dilindungi dan terancam punah, sehingga upaya penangkaran untuk jenis yang potensial harus segera dilakukan.

\section{DAFTAR PUSTAKA}

BKSDA [Balai Konservasi Sumber Daya Alam] (2002) Kawasan konservasi di Sulawesi Utara. Departemen Kehutanan, Manado

Cites (2005) Daftar Appendix

Coates BJ, Bishop KD (2000)

Panduan lapangan burungburung di kawasan Wallacea: Sulawesi, Maluku dan Nusa Tenggara. Birdlife International-Indonesia Programme \& Dove Publications Ptd., Bogor

IUCN (2010). Online

Kinnaird MF (1997) Sulawesi Utara: sebuah panduan sejarah alam. Percetakan Redikencana, Jakarta

Lee RJ, Riley J, Merrill R (2001) Keanekaragaman hayati dan konservasi di Sulawesi bagian Utara. Wildlife Conservation Societies (WCS), Natural Resources, dan Departemen Kehutanan, Jakarta

Peraturan Pemerintah No. 7 Tahun 1999 tentang Pengawetan Jenis Tumbuhan dan Satwa

Pemerintah No. 8 Tahun 1999 tentang Pemanfaatan Jenis Tumbuhan dan Satwa Liar

Sumarto S (2010) Biologi Konservasi. FMIPA UNSRAT, Manado

Sumarto S, Tallei T (2010) Climbing Tangkoko Mountain: Conservation Education Medium. Penerbit Halaman Moeka Publishing, Jakarta

Whitten AJ, Mustafa M, Henderson GS (1987) The Ecology of 
Saroyo , Konsumsi Mamalia, Burung, dan Reptil Liar..... 29

Sulawesi. Gadjah Mada

University Press, Yogyakarta. 
Lampiran 1 Beberapa jenis mamalia, burung, dan reptil liar yang biasa dikonsumsi oleh masyarakat Sulawesi Utara dan statusnya

\begin{tabular}{|c|c|c|c|c|c|c|}
\hline No & Jenis & $\begin{array}{l}\text { Nama } \\
\text { Lokal }\end{array}$ & $\begin{array}{l}\text { Nama } \\
\text { Inggris }\end{array}$ & \begin{tabular}{|l|} 
Status \\
Per- \\
lindungan \\
\end{tabular} & $\begin{array}{l}\text { Kategori } \\
\text { dalam } \\
\text { Redlist IUCN }\end{array}$ & $\begin{array}{l}\text { Appendix } \\
\text { dalam } \\
\text { CIES }\end{array}$ \\
\hline & Mamalia: & & & & & \\
\hline 1. & Macaca nigra & $\begin{array}{l}\text { Yaki } \\
\text { Pantat } \\
\text { Merah }\end{array}$ & $\begin{array}{l}\text { Sulawesi } \\
\text { Crested } \\
\text { Black } \\
\text { Macaques }\end{array}$ & Dilindungi & $\begin{array}{l}\text { Critically } \\
\text { Endangered }\end{array}$ & $\begin{array}{l}\text { Appendix } \\
\text { II }\end{array}$ \\
\hline 2. & $\begin{array}{l}\text { Macaca } \\
\text { nigrescens }\end{array}$ & $\begin{array}{l}\text { Yaki } \\
\text { Pantat } \\
\text { Putih }\end{array}$ & & Dilindungi & Endangered & $\begin{array}{l}\text { Appendix } \\
\text { II }\end{array}$ \\
\hline 3. & Ailurops ursinus & $\begin{array}{l}\text { Kuskus/ } \\
\text { Kuse } \\
\text { Beruang }\end{array}$ & $\begin{array}{l}\text { Sulawesi } \\
\text { Bear- } \\
\text { Cuscus }\end{array}$ & Dilindungi & $\begin{array}{l}\text { Data } \\
\text { Deficient }\end{array}$ & $\begin{array}{l}\text { Appendix } \\
\text { II }\end{array}$ \\
\hline 4. & $\begin{array}{l}\text { Strigocuscus } \\
\text { celebensis }\end{array}$ & $\begin{array}{l}\text { Kuskus } \\
\text { Kerdil }\end{array}$ & $\begin{array}{l}\text { Small } \\
\text { Cuscus }\end{array}$ & Dilindungi & $\begin{array}{l}\text { Data } \\
\text { Deficient }\end{array}$ & $\begin{array}{l}\text { Appendix } \\
\text { II }\end{array}$ \\
\hline 5. & $\begin{array}{l}\text { Babyrousa } \\
\text { babyrussa }\end{array}$ & Babirusa & Babirusa & Dilindungi & Endangered & Appendix I \\
\hline 6. & Sus celebensis & Babi Hutan & $\begin{array}{l}\text { Sulawesi } \\
\text { Wild Boar }\end{array}$ & & & \\
\hline 7. & $\begin{array}{l}\text { Anoa } \\
\text { depressicornis }\end{array}$ & $\begin{array}{l}\text { Anoa } \\
\text { Dataran } \\
\text { rendah }\end{array}$ & $\begin{array}{l}\text { Lowland } \\
\text { Anoa }\end{array}$ & Dilindungi & Endangered & Appendix I \\
\hline 8. & Anoa quarlesi & $\begin{array}{l}\text { Anoa } \\
\text { Dataran } \\
\text { Tinggi }\end{array}$ & $\begin{array}{l}\text { Mountain } \\
\text { Anoa }\end{array}$ & Dilindungi & Endangered & Appendix I \\
\hline 9. & $\begin{array}{l}\text { Cervus } \\
\text { timorensis }\end{array}$ & Rusa & $\begin{array}{l}\text { Timor } \\
\text { Deer }\end{array}$ & Dilindungi & & \\
\hline 10. & $\begin{array}{l}\text { Macrogalidia } \\
\text { musshenbrockii }\end{array}$ & $\begin{array}{l}\text { Musang } \\
\text { Sulawesi }\end{array}$ & $\begin{array}{l}\text { Sulawesi } \\
\text { Palm Civet }\end{array}$ & Dilindungi & Vulnerable & \\
\hline 11. & $\begin{array}{l}\text { Viverra } \\
\text { tangalunga }\end{array}$ & $\begin{array}{l}\text { Musang } \\
\text { Biasa }\end{array}$ & $\begin{array}{l}\text { Malay } \\
\text { Civet }\end{array}$ & & & \\
\hline 12. & $\begin{array}{l}\text { Pterocarpus } \\
\text { Hypomelanus }\end{array}$ & $\begin{array}{l}\text { Kalong } \\
\text { Kecil }\end{array}$ & $\begin{array}{l}\text { Island } \\
\text { Flying Fox }\end{array}$ & & & \\
\hline 13. & Pteropus griseus & $\begin{array}{l}\text { Kalong } \\
\text { Abu-Abu }\end{array}$ & $\begin{array}{l}\text { Grey } \\
\text { Flying Fox }\end{array}$ & & & \\
\hline 14. & $\begin{array}{l}\text { Pteropus } \\
\text { pumilus }\end{array}$ & $\begin{array}{l}\text { Kalong } \\
\text { Kepala } \\
\text { Emas }\end{array}$ & $\begin{array}{l}\text { Golden- } \\
\text { mantled } \\
\text { Flying Fox }\end{array}$ & & Vulnarable & \\
\hline 15. & Pteropus alecto & $\begin{array}{l}\text { Kalong } \\
\text { Hitam }\end{array}$ & $\begin{array}{l}\text { Black } \\
\text { Flying Fox }\end{array}$ & & & \\
\hline 16. & $\begin{array}{l}\text { Acerodon } \\
\text { celebensis }\end{array}$ & $\begin{array}{l}\text { Kalong } \\
\text { Sulawesi }\end{array}$ & $\begin{array}{l}\text { Sulawesi } \\
\text { Flying Fox }\end{array}$ & $\begin{array}{l}\text { Near } \\
\text { Treatened }\end{array}$ & & \\
\hline 17. & $\begin{array}{l}\text { Rousettus } \\
\text { amplexicaudatus }\end{array}$ & $\begin{array}{l}\text { Codot } \\
\text { Roset } \\
\text { Kelabu }\end{array}$ & $\begin{array}{l}\text { Common } \\
\text { Rousette }\end{array}$ & & & \\
\hline 18. & $\begin{array}{l}\text { Rousettus } \\
\text { celebensis }\end{array}$ & $\begin{array}{l}\text { Codot } \\
\text { Roset } \\
\text { Sulawesi }\end{array}$ & $\begin{array}{l}\text { Sulawesi } \\
\text { Rousette }\end{array}$ & & & \\
\hline 19. & $\begin{array}{l}\text { Rousettus } \\
\text { bidens }\end{array}$ & $\begin{array}{l}\text { Codot } \\
\text { Jentinck }\end{array}$ & $\begin{array}{l}\text { Jentinck's } \\
\text { Rousette }\end{array}$ & & & \\
\hline 20. & $\begin{array}{l}\text { Paruromys } \\
\text { dominator }\end{array}$ & $\begin{array}{l}\text { Tikus } \\
\text { Biasa } \\
\text { Sulawesi }\end{array}$ & $\begin{array}{l}\text { Sulawesi } \\
\text { Giant Rat }\end{array}$ & & & \\
\hline
\end{tabular}




\begin{tabular}{|c|c|c|c|c|c|}
\hline 21. & Rattus sp. & Tikus & Rat & & \\
\hline & Burung: & & & & \\
\hline 22. & $\begin{array}{l}\text { Rhyticeros } \\
\text { cassidix }\end{array}$ & $\begin{array}{l}\text { Julang } \\
\text { Sulawesi }\end{array}$ & $\begin{array}{l}\text { Knobbed } \\
\text { Hornbill }\end{array}$ & Dilindungi & $\begin{array}{l}\text { Appendix } \\
\text { II }\end{array}$ \\
\hline 23. & $\begin{array}{l}\text { Penelopides } \\
\text { exharratus }\end{array}$ & Kangkareng & $\begin{array}{l}\text { Sulawesi } \\
\text { Hornbill }\end{array}$ & Dilindungi & $\begin{array}{l}\text { Appendix } \\
\text { II }\end{array}$ \\
\hline 24. & $\begin{array}{l}\text { Megapodius } \\
\text { cumingii }\end{array}$ & $\begin{array}{l}\text { Gosong } \\
\text { Filipina }\end{array}$ & $\begin{array}{l}\text { Philippine } \\
\text { Scubfowl }\end{array}$ & Dilindungi & \\
\hline 25. & $\begin{array}{l}\text { Aramidopsis } \\
\text { plateni }\end{array}$ & $\begin{array}{l}\text { Mandar } \\
\text { Dengkur }\end{array}$ & $\begin{array}{l}\text { Snoring } \\
\text { Rail }\end{array}$ & Dilindungi & \\
\hline 26. & $\begin{array}{l}\text { Gallirallus } \\
\text { striatus }\end{array}$ & $\begin{array}{l}\text { Mandar- } \\
\text { Padi Sintar }\end{array}$ & $\begin{array}{l}\text { Slaty- } \\
\text { Breasted } \\
\text { Rail }\end{array}$ & & \\
\hline 27. & $\begin{array}{l}\text { Gallirallus } \\
\text { torquatus }\end{array}$ & $\begin{array}{l}\text { Mandar- } \\
\text { padi Zebra }\end{array}$ & $\begin{array}{l}\text { Barred } \\
\text { Rail }\end{array}$ & & \\
\hline 28. & Loriculus exilis & $\begin{array}{l}\text { Serindit } \\
\text { Paruh- } \\
\text { Merah }\end{array}$ & $\begin{array}{l}\text { Red-billed } \\
\text { Hanging- } \\
\text { parrot }\end{array}$ & Dilindungi & $\begin{array}{l}\text { Appendix } \\
\text { II }\end{array}$ \\
\hline 29. & Ducula aenea & $\begin{array}{l}\text { Pergam } \\
\text { Hijau }\end{array}$ & $\begin{array}{l}\text { Green } \\
\text { Imperial } \\
\text { Pigeon }\end{array}$ & & \\
\hline 30. & $\begin{array}{l}\text { Macrocephalon } \\
\text { maleo }\end{array}$ & $\begin{array}{l}\text { Maleo } \\
\text { Senkawor }\end{array}$ & Maleo & Dilindungi & Appendix I \\
\hline 31. & Gallus gallus & $\begin{array}{l}\text { Ayam } \\
\text { Hutan } \\
\text { Merah }\end{array}$ & $\begin{array}{l}\text { Red } \\
\text { Jungle- } \\
\text { fowl }\end{array}$ & & \\
\hline 32. & Turnix suscitator & $\begin{array}{l}\text { Gemak } \\
\text { Loreng }\end{array}$ & $\begin{array}{l}\text { Barred } \\
\text { Button- } \\
\text { quail }\end{array}$ & & \\
\hline 33. & $\begin{array}{l}\text { Dendrocycna } \\
\text { arcuata }\end{array}$ & $\begin{array}{l}\text { Belibis } \\
\text { Kembang }\end{array}$ & $\begin{array}{l}\text { Wandering } \\
\text { Whistling- } \\
\text { duck }\end{array}$ & & \\
\hline & Reptil: & & & & \\
\hline 34. & $\begin{array}{l}\text { Python } \\
\text { reticulatus }\end{array}$ & Ular Piton & Python & & \\
\hline 35. & Varanus salvator & Biawak & $\begin{array}{l}\text { Monitor } \\
\text { lizard }\end{array}$ & & \\
\hline 36. & Chelonia mydas & $\begin{array}{l}\text { Penyu } \\
\text { Hijau }\end{array}$ & Blue Turtle & Dilindungi & Appendix I \\
\hline 37. & $\begin{array}{l}\text { Eretmochelys } \\
\text { imbricata }\end{array}$ & $\begin{array}{l}\text { Penyu } \\
\text { Sisik }\end{array}$ & $\begin{array}{l}\text { Hawksbill } \\
\text { Turtle }\end{array}$ & Dilindungi & $\begin{array}{l}\text { Appendix } \\
\text { II }\end{array}$ \\
\hline 39. & $\begin{array}{l}\text { Dermochelys } \\
\text { coriacea }\end{array}$ & $\begin{array}{l}\text { Penyu } \\
\text { Belimbing }\end{array}$ & $\begin{array}{l}\text { Olive } \\
\text { Ridley } \\
\text { Turtle }\end{array}$ & Dilindungi & Appendix I \\
\hline
\end{tabular}

